\title{
Experimentation of Innovative Learning Models in Terms of Students Multiple Intelligences Among Midle School Students in Demak District
}

\author{
Muhamad Asif Cahya Aji Nugroho ${ }^{1}$ Budiyono $^{2}$, Isnandar Slamet ${ }^{3}$
}

\begin{tabular}{l} 
ARTICLE INFO \\
\hline Article History: \\
Received 10.10.2018 \\
Received in revised form \\
28.01 .2019 \\
Accepted \\
Available online 01.04 .2019
\end{tabular}

\begin{abstract}
The purpose of this study was to find out from each mathematical learning model, Interactive Setting Cooperative Learning Model (PSIK), Course Review Horey (CRH) and Conventional model, which ones provide better mathematics learning achievements, students who have mathematical intelligence, visual, kinesthetic, or interpersonal in middle school. This research method of this study is quasi-experimental research or pre-experimental research with research design using $3 \times 4$ factorial designs. The population in this study is the entire students 8 th grade SMP N in Demak District. The fokus material in The Material Geometry Flat Side. Sampling was conduct with stratified cluster random sampling techniques. Instruments used to collect data are a questionnaire of multiple intelligences and mathematics learning achievement test. The prerequisite test includes the population normality test using the Lilliefors method and the homogeneity test of population variance using the Bartlett method. With $\alpha=0,05$. Hypothesis testing of the study are analysis of two variance with unequal cell. Based on the results of hy pothesis testing is [Fab 4,3390>2,14] with the decision of the $\mathrm{H}$ test are rejected, this means that there is an interaction between the learning model and students' multiple intelligence towards mathematics learning achievement.
\end{abstract}

C) IJERE. All rights reserved

Keywords:

Students' Multiple Intelligence, PISK, Mathematics Learning Achievement, CRH, Conventional.

\section{INTRODUCTION}

For the qualifications regarding teaching profession to be gained, and for the positive attitudes to be acquired, the process of being prepared for teaching profession should be sufficient. Mathematics as one of the basic sciences plays an important role in various disciplines. In addition, mathematics learning can inspire in providing the skills of its application in everyday life as well as in studying various sciences. One important characteristic of mathematics is to have an abstract object. Something abstract generally has a high level of understanding, thus causing many students have difficulty in learning mathematics. How ever, as a teacher, should try to reduce the abstract nature by always innovating to facilitate students capture the material provided. According to Ibrahim ( Karagoz, 2016 ) A teacher must always use objects, if the objects are not available in nature, the teacher must use shapes and pictures. In addition, the teacher must let students to touch the objects and teach the subjects in a realistic way.

In general it can be understood that the low quality of the human resources of the Indonesian people today is a result of the low quality of education. According to Mullis et al (2013) from the results of the Trends study in the International Mathematics and Science Study (TIMMS) on 2015 grade students' mathematics achievement and students science achievement of 8 grade Indonesian mathematics learning achievement ranked 46 out of 51 participants. While the results of the PISA study (Program for International Student Assessment) in 2015 showed that Indonesia could only be ranked 69 out of 76 countries (OECD, 2015). This shows that Indonesian students have not shown satisfactory achievements. According to Duman and Karagoz (2016) as the education system is one of the most critical factors for the development of a country, and teachers are the most critical parts of this system. Therefore teachers need to innovate to improve the mathematics learning achievement, especially for Middle School students.

In the mathematics learning that is the basis of thinking is that the students enter the classroom with knowledge, ability, and motivation so diverse that the learning activities need a model of learning that empowers students actively in accordance with the type of intelligence they have. Good learning activities, if the teacher preparing well-planned planning of the completeness of learning tools such as learning materials and the use of appropriate learning models are used so as to improve learning outcomes.

\footnotetext{
1 coresponden email asifnugroho@gmail.com/ orcid.org/0000-0003-4931-4046

2 email : budiyono@staff.uns.ac.id/orcid.org/0000-0003-0750-5370

3email : isnandar06@yahoo.com/ orcid.org/0000-0003-4931-4046

Postgraduate, Universitas Negeri Sebelas Maret
} 
According to Davies (1981) teaching planning that must be prepared by the teacher is analyzing the task, identifying the need for practice / learning, writing learning goals. In this way a teacher is able to predict learning tasks that must be done before the teacher chooses to use the resources needed to achieve the expected goals.

\section{Situation of the Problem}

Mathematics learning, although it can't be said for all subject matter, is still a lot of learning in schools that use conventional models. According to Kusnandar (2007), the nature of conventional learning is more centered on the teacher so that the implementation less attention to the overall learning situation. In addition, students do not participate directly in a learning, students become less focused, bored during the lesson. Under these conditions, teachers are required to be more creative in developing learning models so that students do not feel bored and feel happy in following the lesson. One of the alternatives to solve the problem there is, in the implementation of cooperative learning model in students' participation and collaboration in a small group of heterogeneous to solve a problem. This is in line with Stahl's explanation (Solihatin and Raharjo, 2007) that cooperative learning model, students as part of a system of collaboration by achieving an optimal outcome in learning. According to Dyson and Grineski (Atte and Baker, 2007) states that classes that use cooperative learning with heterogeneous teams are able to encourage students in positive interactions to achieve team goals. Cooperative learning model proved to be better than conventional learning this is supported by research conducted by Ling, Ghazali and Raman (2016) stated that the learning with cooperative learning strategy more improve mathematics achievement than the learning without using cooperative learning strategy.

Some models of cooperative learning that emphasize students' participation and teachers to deliver lesson material can use collaboration, between Interactive Setting Cooperative learning (PISK) and Course Review Horay (CRH). According to Ratumanan (2002), the result of model modification of cooperative learning that emphasizes the student's broad interaction, there is students (Student-Student = S-S), studentlearning materials (Student-Learning Material-Student $=\mathrm{S}$-LM) teachers (Student-Teacher $=\mathrm{S}-\mathrm{T}$ ), StudentLearning Material-Student (S-LM-S), and Student-Learning Material-Teacher (S-LM-T) ). This interaction is essential efforts for knowledge construction and enhancement of academic and social skills. According to Devidson (Baroody, 1993), student interactions are used to construct mathematical knowledge, develop problem solving and thinking competitions, encourage trust, and gain social skills.

One of the other lessons is the Course Review Horay. It is a cooperative learning method that uses a box filled with questions and numbered to write down the answer and shout horay if it is true (Shoimin, 2014). In this learning model students are invited to play and work together to solve problems, so that learning will be more active and fun. According Janah and Subroto (2019) In the cooperative learning model students who are passive in groups only follow active students and only active students who understand more about the questions given by the teacher. This shows that active students are more aw are of receiving lessons than students who are not active.

The model of PISK and CRH empowerment emphasizes student interaction. In the PISK model students actively engage in activities, actively think, conceptualize, and give meaning to the things be studied. In CRH model, student interaction is done by fun method and not boring through yells. The function of the teacher provides a limited explanation in the form of questions that stimulate students' thinking and can lead the students there problem solving faced, so that the mathematical concepts are found by the students themselves.

To improve the learning of mathematics not only seen in the learning model that used but also can seen from the more dominant student intelligence. Gardner and Hatch (1998) stated that in the person having 8 intelligences but in certain people have a more prominent intelligence. In this study the researcher only drawn four multiple students intelligences, namely logical-mathematic intelligence, visual, kinesthetic and interpersonal. This is seen from eight multiple intelligences, these four intelligences are the dominant intelligence students have when learning mathematics. Although some students at that stage may learn by using a combination of these four intelligences, most students will be more likely to be in one of the four. Learning activities must tailored to the students' intelligence, because students who can adjust their 
intelligence with the learning done will be easier in receiving and processing information and using in learning, so that learning objectives will be accomplished in accordance with the expected.

\section{Aim of the Study}

Seeing these problems, the authors are interested to conducting research on the application of PISK, $\mathrm{CRH}$, and Conventional models on mathematics learning in terms of students' multiple intelligence, which this research has not done before and this research was expect to contribute to improving student learning achievement. The purpose of this research is to know for each model of mathematics learning, which provides better mathematics learning achievement, students with logical, visual, kinesthetic or interpersonal logical intelligence types.

\section{METHOD}

The research is conducted in quantitative model. The sample of the research population in this research is all of the students in 8th grade at Midle School in Demak of the subjects' geometry flat side in the even semester of the academic year 2017/2018. The result of the calculations for sampling is 3 of Midle School. The high category is SMPN 3 Mranggen. The medium category is SMPN 1 Karangawen, and the low category is SMPN 1 Guntur. The sample in this research around 263 students around 14-15 year age, with details of 172 students in the experimental class consisting of 85 students on the PISK model with 39 female and 46 male. The CRH model consisting of 87 students with 48 female and 39 male, and 91 students in the control class with 41 female and 50 male. In this research, the researcher used stratified random sampling technique. This study consists of free variables, there are learning model of mathematics and students' multiple Intelligences. The dependent variable is learning mathematics achievement. The design of this research is quasi-experimental research with the planning factorial research with $3 \times 4$. The research design will describe in the following TABLE 1.

Tabel 1. Research Plans

Student Multiple Intelligence(B)

\begin{tabular}{|c|c|c|c|c|}
\hline $\begin{array}{l}\text { Model of Learning } \\
\text { Mathematics }(A)\end{array}$ & $\begin{array}{c}\text { Logical } \\
\text { Mathematics } \\
\left(b_{1}\right)\end{array}$ & $\begin{array}{l}\text { Visual } \\
\qquad\left(b_{2}\right)\end{array}$ & $\begin{array}{l}\text { Kinesthetic } \\
\qquad\left(b_{3}\right)\end{array}$ & $\begin{array}{c}\text { Interpersonal } \\
\left(b_{4}\right)\end{array}$ \\
\hline $\begin{array}{l}\text { Interaktive Setting Cooperative } \\
\text { Learning (PISK) }\left(a_{1}\right)\end{array}$ & $(a b)_{11}$ & $(a b)_{12}$ & $(a b)_{13}$ & $(a b)_{14}$ \\
\hline $\begin{array}{l}\text { Course Review Horay } \\
\qquad(C R H)\left(\mathrm{a}_{2}\right)\end{array}$ & $(a b)_{21}$ & $(a b)_{22}$ & $(a b)_{23}$ & $(a b)_{24}$ \\
\hline Konvensional $\left(\mathrm{a}_{3}\right)$ & $(a b)_{31}$ & $(a b)_{32}$ & $(a b)_{33}$ & $(a b)_{34}$ \\
\hline
\end{tabular}

The operational definitions and indicators of each variable are

Mathematics learning achievement of students. Learning achievement is the result achieved by someone in a learning effort as stated in report cards. The indicators in the assessment are in the form of tests of students' mathematics learning achievement on the subject matter. Build flat side spaces.

Learning Model is a plan or pattern that is arranged systematically and contains strategies and syntax of learning. Indicators of learning activities are carried out according to the syntax.

Compound Intelligence of students is a multiple intelligence ability to solve a problem faced in life. The indicator used is the intelligence questionnaire score that students have. which is divided into several aspects of multiple intelligence.

Logical Mathematical Intelligence is the ability to make mathematical calculations, inductive and deductive reasoning, build logical relationships, produce hypotheses, solve problems, make critical thinking and understand numbers in the form of geometric and abstract symbols. Indicators used work with numbers, solve problems, analyze situations, Understand how things work, Show accuracy in problem solving, Work with gradual directions. 
Visual intelligence is the ability for spatial repetition of individual thoughts or forming an imagination, thinking with images, shapes and lines, observing and understanding three-dimensional objects. Indicators used Scribbling, painting or drawing, creating a three-dimensional look, observing and creating maps and diagrams, unpacking and rearranging items.

Interpersonal intelligence is the most important type of intelligence in everyday life, which allows oneself to possess knowledge and take responsibility for his own life. Indicators used Glad to make lots of friends, lead, share, and mediate, love to build interactions, become effective team members.

Kinesthetic intelligence is the capacity to express oneself with movements, gestures and facial expressions, using effective coordination of the brain and body. The indicators used are solving problems with body movements, mastering one type of sporting activity, being able to manage objects, respond and reflex, feeling bored when silent for a long time.

\section{Material}

The techniques to collecting data in this research are documentation, questionnaires, and test on April until May 2018. The documentation method is the technique that is used to collecting students ability. Questionnaire is method to collect data of students multiple intelligence. The multiple choice test will be used to collecting mathematics students' achievement. The test pieces of the test instrument include content validation, the lurch, distinguishing power, and reliability. The Questionnaire, which revealed single factor on five-point likert type scale, included 60 items, out of which 35 were positive and 25 were negative.

Trials of compound intelligence questionnaires include content validity, internal consistency, and reliability. A valid instrument according to content validity if the content of the instrument has been a representative sample of the overall contents of the measured thing (Budiyono, 2015). Validity is carried out by a team of experts who assess questionnaires based on content, construction and language. From 3 experts, the questionnaire used was valid and could be used for research. Biserial correlation formula of Karl Pearson product moment used to calculate the internal consistency. The questionnaire question items used to collect multiple student intelligence data are question items that have internal consistency of more than or equal to 0,3 . Based on the results of the calculation of the internal consistency of the multiple intelligence questionnaire items, from the 60 items of multiple intelligence questionnaires tested, the 40 questionnaire was more than 0.3 and use for research. An instrument is called reliable if the measurement results with the instrument remain the same if the measurements are carried out on the same person at different times or in different people (but have the same condition) at the same time or at different times (Budiyono, 2015). Reliability test results get Alpha Cronbac'h coefficient of more than 0.7 on all variables so declared reliable (Sugiyono, 2010). The results of reliability of logical mathematic variable obtained alpha value 0.702 , visual variable 0.714 , kinesthetic 0.797 and interpersonal 0.707 . From these results can be concluded that all the instruments reliables and trusted as a data collection tool in research.

\section{Data Analyses}

Before doing the experiment, first conducted a test of balance on the students' mathematical ability early in the experimental class and the control class. This balance test to test the similarity of the initial ability average. Before the balance test is carried out, a prerequisite test is conducted which includes the population normality test using the Lilliefors method and a test of population variance homogeneity using the Bartlett method with $\alpha=0,05$. The prerequisite test includes the population normality test using the Lilliefors method and the homogeneity test of population variance using the Bartlett method with $\alpha=0,05$. Balance test for data on the initial mathematical ability using a variance analysis of one cell different path, with a significance level of 0.05 . A balance test of early mathematical ability data using a variance analysis of one cell path is not the same as the conclusion that the experimental and control classes have a balanced initial mathematical ability. Hypothesis testing uses analysis variance two path with different cell and multiple comparison tests with the Scheffe method if the result shows that $\mathrm{H}_{0}$ rejected.

\section{FINDINGS}

The population normality test using the Lilliefors method. Based on the results of the population normality test on students' initial mathematical ability data, the sample in the PISK model [Lhit $0.0851<\mathrm{L}_{0.05 ; 85}$ 
Nugroho,M.A.C.A., Budiyono \& Slamet,I.(2019). Experimentation of innovative learning models in terms of students multiple intelligencesamong midle school students in Demak district. International Journal of Educational Research Review,4(2),262-268.

0.0961], CRH model [Lhit $0.0927<\mathrm{L} 0.05 ; 870.0950$ ] and the conventional model [Lhit $0.0669<\mathrm{L} 0.05 ; 91$ 0.0929] has a Lhit value $\notin \mathrm{DK}$. This means, the decision of the population normality test for each sample is Ho not rejected.

The test of population variance homogeneity using the Bartlett method with $\alpha=0,05$. Based on the test results of population variance homogeneity of students' initial ability data, it was obtained at 1.3784 less than the value of 5.991 then $\notin \mathrm{DK}$. This means that the decision of the population variance homogeneity test is $\mathrm{H}_{0}$ not rejected with a significance level of 0.05 . Thus, the variances of the three populations are the same or homogeneous.

Balance test for data on the initial mathematical ability using a variance analysis of one cell different path, with a significance level of 0.05 . Data obtained $F_{\text {obs }} 2,2417<F_{0,05 ; 2 ; 279} \quad 3,02$ so that $F_{\text {obs }} \notin$ DK concluded that the experimental class and the control class had a balanced mathematical initial abilities.

From the study data obtained that the average student achievement compared to the learning model and multiple intelligence categories, in the PISK learning model had a marginal mean of 73.0753, CRH learning model 69.4624 and Conventional 66.127. On multiple intelligences students of logical-mathematical intelligence have a marginal mean of 66.7273, visual 74.7119, kinesthetic 66.6301 and interpersonal 68.5538 . From this data, it can be seen that each model of learning and students' multiple intelligences have a relationship with student achievement, so it can be concluded also that the learning model have an interaction with multiple intelligences.

To prove this connection, a two-w ay variant analysis test was use, along with the results of the research data. The Analysis Variations will be describing in the following TABLE 2.

Tabel 2 Summary Analysis Variations

\begin{tabular}{ccccccc}
\hline Source & $J K$ & $d k$ & $R K$ & $F_{\text {obs }}$ & $F_{\alpha}$ & Keputusan Uji \\
\hline Learning Model $(A)$ & 3111,2684 & 2 & 1555,6342 & 6,8749 & 3,03 & $H_{0}$ rejected \\
Multiple intelligence $(B)$ & 2478,8606 & 3 & 826,2869 & 3,6517 & 2,64 & $H_{0}$ rejected \\
Interaction $(A B)$ & 5890,9493 & 6 & 918,8249 & 4,339 & 2,14 & $H_{0}$ rejected \\
Error $(G)$ & 56795,52 & 251 & 231,9951 & - & - & - \\
Total & 682763,6 & 262 & - & - & - & - \\
\hline
\end{tabular}

From the data above, the results are that Hypothesis testing of Learning Model $\left[F_{A} \quad 6,8749>F_{0,05 ; 2,233}\right.$ 3,03] then $F_{A} \in D K$ with the decision of the $\mathrm{H}_{0}$ test are rejected, this means that there is an interaction between each of the learning model towards mathematics learning achievement. Hypothesis testing of Multiple intelligence $\left[\begin{array}{ll}F_{B} & 4,3390>F_{0,05 ; 3,233} \\ 2,14\end{array}\right]$ then $F_{B} \in D K$ with the decision of the $\mathrm{H}_{0}$ test are rejected, this means that there is an interaction between each of students' multiple intelligence tow ards mathematics learning achievement. Hy pothesis testing of $\left[F_{A B} 4,3390>F_{0,05 ; 6,233} 2,14\right]$ then $F_{A B} \in D K$ with the decision of the $\mathrm{H}_{0}$ test are rejected, this means that there is an interaction between the learning model and students' multiple intelligence tow ards mathematics learning achievement.

In the results of the two-way analysis of variance, $\mathrm{Ho}$ rejected. The study continued by a multiple comparison test to find out where the relationship between the learning model and multiple intelligence students is located.

On the results of the comparative test between cells on the same line, between students multiple learning and intelligence models. The data were obtained that only in the PISK model with logical mathematical and visual intelligence with results $\left[F_{\mathrm{obs}} 20,98>F_{0,05 ; 11251} 20,1\right]$ and the decision show Ho rejected, this meant only logical mathematical and visual intelligence had an interaction with the PISK model of student learning achievement. The Comparative test result will describe in the following TABLE3. 
Table 3 Comparative test results between cells on the same line.

\begin{tabular}{|c|c|c|c|c|c|c|c|}
\hline$H_{0}$ & $F_{o b s}$ & $F_{\text {tabel }}$ & Decision result & $F_{\text {tabel }}$ & Decision result $H_{0}$ & $F_{\text {tabel }}$ & Decl \\
\hline$\mu_{11}=\mu_{12}$ & 20,98 & 20,1 & $\mu_{21}=\mu_{22} 0,06$ & 20,1 & $H_{0}$ not rejected $\mu_{31}=\mu_{32}{ }^{0,58}$ & 20,1 & $H_{0}$ not rejected \\
\hline$\mu_{11}=\mu_{13}$ & 0,54 & 20,1 & $H_{0}$ not rejected $\mu_{21}=\mu_{23} 2,09$ & 20,1 & $H_{0}$ not rejected $\mu_{31}=\mu_{35,60}$ & 20,1 & ejected \\
\hline$\mu_{11}=\mu_{14}$ & 14,48 & 20,1 & $H_{0}$ not rejected $\mu_{21}=\mu_{24} 3,01$ & 20,1 & $H_{0}$ not rejected $\mu_{31}=\mu_{34}$, & 20,1 & $H_{0}$ not rejected \\
\hline$\mu_{12}=\mu_{13}$ & 4,16 & 20,1 & $H_{0}$ not rejected $\mu_{22}=\mu_{232,55}$ & 20,1 & $\mathrm{~d} \mu_{32}=\mu_{33}$ & 20,1 & $H_{0}$ not rejected \\
\hline$\mu_{12}=$ & 6,85 & 20,1 & rejected $\mu_{22}=\mu_{241,75}$ & 20,1 & $H_{0}$ not rejected $\mu_{32}=\mu_{34}^{0,35}$ & 20,1 & $H_{0}$ not rejected \\
\hline$\mu_{13}=$ & $L$ & 20,1 & $H_{0} \mathrm{r}$ & 20,1 & 0,03 & 20,1 & \\
\hline
\end{tabular}

\section{RESULT, DISCUSSION, AND SUGGESTIONS}

Based on the comparative test results obtained the following points. From the results of comparative test between cells on the same line obtained the following things. In students who subjected to PISK model, students' mathematics learning achievement on visual intelligence is better than mathematical logical intelligence. It is inversely proportional to the Lestari (2015) stating that on LBC, student learning model with logical mathematical intelligence has learned that accomplishment as good as visual int elligence. This result is caused by the stages in the PISK model is more dominant using the image so that students with visual intelligence tends to better understand the problem compared with students who have logical mathematical intelligence. It is in accordance with statement of Gardner (2013) in Yalmanci and Candidate (2013) which states that students with visual intelligence has the ability to form a stretch of the imagination, be able to think in images and form a three-dimensional object. In mathematical, kinesthetic and interpersonal logical intelligence has the same good learning achievement, this is due to the existence of individual unit test questions, it forces students with each category of intelligence to expand interaction, explore as much knowledge as possible and participate in discussion activities maximum in math especially the material geometrical flat side.

To the students who are the model of the CRH, the achievements of students learning math with the logical mathematical intelligence, visual, kinesthetic, interpersonal and has the same good study achievements. Researches support this finding by Pradana (2014) that states there is no difference between learning achievements that have logical mathematical intelligence, visual and interpersonal. On students who are of the conventional model, students learn math achievement with logical mathematical intelligence, visual, kinesthetic and interpersonal has the same learning achievement. That is because the learning centered on the teacher, so that learning becomes boring, and makes students less motivated to learn.

In the learning process, teachers should pay more attention to the learning techniques tailored to the subjects. In addition, teachers should adjust between mathematics lessons, learning model used and the attention to multiple intelligences owned by each student, because each student character in the learning process has an effect on student achievement. Further studies are needed that compare learning models with other students' multiple intelligence categories. Discussions about learning models that are in accordance with the individual intelligence possessed by students in mathematics will often be discussed in the future. The researcher show that the interactive learning model and multiple intelligences of students are very influential on mathematics learning achievement, especially on the subjects' geometry flat - side, it is better to use an interactive model of cooperative settings (PISK) in students who have visual intelligence.

\section{REFERENCES}

Arikunto, S. (2010). Prosedur Penelitian Suatu Pendekatan Praktek. Jakarta: Rineka Cipta.

Attle, S. \& Baker, B. (2007). Cooperative learning in a competitive environtment: Classrom applications. International Journal of Teaching and Learning in Higher Education, 19(1), pp. 77-83.

Baroody, M. F. (1993). Interaksi Sosial dan Multi intelegensi . Malang: P3T IKIP Malang.

Budiyono. (2015). Penilaian Hasil Belajar. Surakarta: UNS Press.

Davies, I. K. 1981. Instructional technique. New York: McGraw Hill Book Company. 
Nugroho,M.A.C.A., Budiyono \& Slamet,I.(2019). Experimentation of innovative learning models in terms of students multiple intelligencesamong midle school students in Demak district. International Journal of Educational Research Review,4(2),262-268.

Duman, T., Karagoz, S. (2016). An evaluation of Turkish teacher education system compared to other models in different countries. International Journal of Educational Research Review, 1( 1), pp. 1-13.

Gardner, H. \& Thomas, H. (1989). Multiple intellegence go to school educational implications of the theory of multiple intellegence. Journal Educational Researcher, 18(8),pp. 4-10.

Janah, I.I.N., \& Subroto, W.T., (2019). Comparison Of cooperative learning models with inquiry on student learning outcomes. International Journal of Educational Research Review, 4(2), 178-182.

Karagoz, S. (2016). Opinions and suggestions regarding various subjects on the educational guidance in the second constitutional era. Journal of Family, Counseling, and Education, 1(1), 1-9.

Kusnandar, (2007). Guru Profesional Edisi Revisi. Jakarta: Raja grafindo Persada.

Lestari, S.I .(2015). Eksperimentasi Model Pembelajaran Problem Based Learning (PBL), Discovery Learning (Dl), Dan Problem Possing (PP) Ditinjau Dari Kecerdasan Majemuk Siswa Pada Materi Kubus Dan Balok Smp Negeri Kabupaten Demak Tahun Ajaran 2014/2015. Jurnal Elektronik Pembelajaran Matematika Universitas Negeri Sebelas Maret, 3(8), pp. 811-823.

Ling, W. N., Ghazali ,M. I., \& Raman, A.(2016). The effectiveness of student teams-achievement division (STAD) cooperative learning on mathematics achievement among school students In Sarikei District Sarawak. International Journal of Advanced Research and Development, 1 (3), pp. 17-21.

Mullis, I.V.S., Martin, M.O., \& Editors (2013). TIMSS 2015 assessment frameworks. Chestnut Hill MA: TIMSS \& PIRLS International Study Center Boston Collage.

OECD. (2015). PISA 2015 draft mathematics framework. New York: Columbia University.

Pradana, L. N. 2014. Eksperimentasi Model Pembelajaran Kooperatif Tipe Numbered Heads Together dengan Pendekatan Contextual Teaching and Learning pada Materi Pokok Bangun Ruang Sisi Datar Ditinjau dari Kecerdasan Majemuk Siswa SMP Negeri Kelas VIII Sekota Madiun. Surakarta: UNS Surakarta.

Ratumanan, T.G.(2002). Pengenalan Model Pembelajaran Interaktif dengan Setting Kooperatif. Buletin Pendidikan Matematik : Universitas Surabaya.

Shoimin, A. (2014). Model - Model Pembelajaran Inovatif dalam Kurikulum 2013. Jakarta : Rineka Cipta.

Sugiyono. (2010). Statistika Untuk Penelitian. Bandung: Alfabeta.

Solihatin \& Raharjo. (2007). Model-Model Pembelajaran Matematika Sekolah. Seminar Pengembangan ModelModel Pembelajaran Matematika Sekolah : Universitas Negeri Yogyakarta. 